\title{
Darwin's Revision
}

Darwin published The Descent of Man in 1871. It contained the following seemingly common-sense sentence, so characteristic of Darwin's anecdotal style, his roundabout way of making his point:

In the agony of death a dog has been known to caress his master, and every one has heard of the dog suffering under vivisection, who licked the hand of the operator; this man, unless he had a heart of stone, must have felt remorse to the last hour of his life. ${ }^{1}$

Had everyone really heard of this in 1871? Darwin gives no clue of the identity of this man, whether it were real or imagined, a trope of scientific cruelty that was somehow already in the air or a repetition of an anecdote on the lips of the chattering classes. As Darwin was writing, there were the first glimpses of antivivisectionist sentiment in public discourse, but nothing like an organized movement. This aside appeared in a long discussion on the evolution of sympathy, its limits and the possibilities for its extension. Darwin's sentimental note was published without an inkling that it might have political traction. Events soon overtook him.

By the time Darwin came to do the revisions for a second edition of Descent, the ethical landscape had changed. Darwin's common-sense aside had become politically sensitive. There was a risk, and not a small one, of it being used against him, to align him with his enemies and to alienate him from his friends and allies in the worlds of science and medicine. Darwin did not like pain, or cruelty or the idea that pain was intrinsic to scientific investigation, but Darwin did believe in the virtues of experiment, and he knew that physiology was at the centre of medical and scientific progress. It was the crucible of new knowledge about the human and other species, and it was the hope for new remedies against disease and suffering. He also knew,

${ }^{1}$ Charles Darwin, Descent of Man (1871), i, 39. 
from his close friends and associates who involved themselves in experiments of this kind, that vivisection did not harden the heart or diminish sympathy. Given his position as the nation's, if not the world's, most famous man of science, of course he took the side of his friends and colleagues in the burgeoning controversy over vivisection. Instead of throwing away this line about the dog licking the hand, he amended it and, in so doing, captured the whole spirit of a debate that he would inspire and serve and that would outlive him by a generation:

In the agony of death a dog has been known to caress his master, and every one has heard of the dog suffering under vivisection, who licked the hand of the operator; this man, unless the operation was fully justified by an increase of our knowledge, or unless he had a heart of stone, must have felt remorse to the last hour of his life. ${ }^{2}$

It is not that Darwin, in between editions of Descent, changed his mind. On the contrary, Darwin's conviction about the virtues of experimental research were unwavering. It simply became necessary, between 1871 and 1874 , to stress the point that the commission of suffering in the scientific laboratory could be justified, and without compunction, and without damage to the sensibilities of the scientist, on the basis that increases in knowledge were virtuous and necessary in their own right. What was not stated here, although Darwin made much of the point elsewhere, is that the vast majority of experiments using vivisection involved no suffering because of the availability of anaesthetics. Most dogs could not lick the hand of the vivisector because they were unconscious in the operation and destroyed thereafter. Darwin's point, then, was that even painful vivisection could be justified and, in the case of advances of knowledge, would be justified. What had happened in the intervening years that had required Darwin to make this amendment?

\section{Born, or at Any Rate Bred, in a Handbook}

The Handbook for the Physiological Laboratory was published in 1873. The antivivisection movement had been growing prior to this, especially via the pens of Richard Holt Hutton (1826-97), editor of the Spectator, and Frances Power Cobbe (1822-1904), who would become the de facto leader of the movement to abolish vivisection. But it was the publication of the Handbook that seemed to provide, to the opponents

${ }^{2}$ Charles Darwin, The Descent of Man and Selection in Relation to Sex, 2nd edn (London: John Murray, 1874), 70, emphasis added. 
of physiology in particular, clear proof that the practice of vivisection had blunted the morals of its practitioners. ${ }^{3}$ Its two volumes, the first descriptive, the second illustrative, were compendious in their descriptions of physiological experiments, compiled by the foremost physiological researchers in the country at the time. For all their thoroughness, they omitted any explicit reference to the need for humane treatment of animals and the general application of anaesthetics. To the almost immediate regret of most of the editors, these things were taken for granted. Moreover, they failed to address the context in which the handbook might be used, namely under the direction of men such as themselves in proper laboratory conditions. It was not meant for the curious youngster at home, but their failure to say so in the book itself was made to look as if the Handbook was a teach-yourself guide for amateurs, an outlet for the development of puerile creativity in the line of cruelty. The Handbook served as the announcement of physiology as an established field in England, immediately setting off multiple alarm bells. There were concerns about the Germanification of English science and, with it, the loss of English morals; worries about the calcification of public opinion, as defined by a 'new priesthood' of scientists; deeply held fears about the end of civilization, if tender mercies were abandoned to unbounded curiosities; and anxiety that cruelty to animals for that is how vivisection was commonly represented - was the sign of all these things. ${ }^{4}$ The charge of cruelty must be understood in context. It presupposed a motive of enjoyment or satisfaction in the causing of pain. The capacity of animals to experience pain played a large part in the controversy, but antivivisection can only really be understood if this question of intent is taken seriously. For, as the medical establishment would come to argue repeatedly, animals were put to pain in the service of humans in countless other capacities, from food to clothing to conveyance, and against these the antivivisectionists seemed not to cavil. It was, then, the practices of the men involved in vivisection that particularly cast a pall. The absences and omissions in the Handbook were seized upon as evidence of their societal danger, through their

${ }^{3}$ John Burdon Sanderson, ed., Handbook for the Physiological Laboratory, by E. Klein, John Burdon Sanderson, Michael Foster and Thomas Lauder Brunton, 2 vols (London: J \& A Churchill, 1873). For the initial activities of antivivisectionists, see Rob Boddice, The Science of Sympathy: Morality, Evolution and Victorian Civilization (Urbana: University of Illinois Press, 2016), 54, 66, 73. See also Patrizia Guarnieri, 'Moritz Schiff'. On antivivisection and the Handbook in particular, see Richard D. French, Antivivisection and Medical Science in Victorian Society (Princeton, NJ: Princeton University Press, 1975), 47-50.

4 The label 'priesthood' for scientists was in circulation by 1874, courtesy of Francis Galton, but was also used as a stick to beat them. See Ouida (Maria Louise Ramé), The New Priesthood: A Protest against Vivisection (1893), and Boddice, Science of Sympathy, 31. 
callousness. ${ }^{5}$ Still, a relatively simplistic formulation of animal cruelty was very often the rhetorical vehicle that carried these more nuanced and complex arguments. Much of the strategic defence of experimental medicine, therefore, would come to concern the removal of attention from the animal to the broader moral implications and societal benefits of experimental practices. Hence Darwin's revision. An increase in knowledge altered the moral weight of the vivisector's intentions. It removed the possibility of cruelty and replaced it with an implication of its opposite, for the accretion of knowledge in science and medicine was always, in the whole period under consideration here, connected to beneficent applications. Humans and animals alike could thank such an increase in knowledge for a reduction, writ large, of their suffering.

The heightened attention on the question of vivisection in England, and the spectre of its apparent rate of increase as a professional or, worse, amateur occupation, led to attempts at legislation. ${ }^{6}$ Frances Power Cobbe was behind the drafting of the first Bill to be introduced into Parliament in early May 1875. It was not an abolitionist Bill, but it did propose to subject vivisection to the scrutiny of the Home Secretary and introduced the notion of licensing and penalties for failure to abide by the use of anaesthetics. In order to regain control, the scientific establishment drew up its own Bill. To defuse the antivivisectionist argument and to allow scientists to go on with their experiments, they suggested their own legislation. The intention was to regulate experimentation, not to stifle it; to give legislative force to the feelings of humanity that experimental scientists professed. In this act of compromise, of a particularly English form of incremental legislative reform, Charles Darwin was a major architect. In fact, the Bill was demonstrably subject to Darwin's imprimatur, though it quickly got out of control.

Darwin wrote to Huxley in January 1875, concerned about Cobbe's circulation of a memorial, for which she was gathering signatures, to petition the Royal Society for the Prevention of Cruelty to Animals (RSPCA) to formulate an antivivisectionist Bill. He was concerned at Parliament's 'thoroughly unscientific' nature and the likelihood that 'some stringent law' might be passed 'to check or quite stop the revival of Physiology in this country', which would be 'a great misfortune'. Still, Darwin was alarmed by the notion that anaesthetics were not always used when they could have been and that repetitions of experiments were made

${ }^{5}$ For the long history of callousness as a threat to civilization, and its connections to medicine in particular, see Rob Boddice, A History of Feelings (London: Reaktion, 2019), 131-63.

6 The account by French, Antivivisection, 69ff., is still the best. 
needlessly. If Cobbe and her allies were 'flagrantly unjust towards physiologists', it might still be in the hands of 'all biologists ... to save suffering'. He suggested a petition, 'signed by eminent physiologists \& biologists, praying for reasonable legislation on the subject' in order to 'counteract the passionate appeals of the promoters of the present movement'. $\mathrm{He}$ bade Huxley to canvass support among physiologists and warned that if 'nothing is done I look at the noble science of Physiology as doomed to death in this country'. ${ }^{7}$ With this, Darwin assumed the role of defending vivisection, through the tactical method of legislatively regulating it.

Huxley agreed with Darwin 'about vivisection as a matter of right and justice in the first place, and secondly as the best method of taking the wind out of the enemy's sails' and set about engaging John Burdon Sanderson (1828-1905). ${ }^{8}$ Burdon Sanderson then engaged John Simon (18161904), about whom we shall hear more; William Sharpey (1802-80); Robert Christison (1797-82); Henry Acland (1815-1900); George Rolleston (1829-81); William Gull (1816-90) and Michael Foster (1836-1907): the old guard, with the exception of Foster, who perhaps were most likely to share Darwin's mixed feelings of needing to defend medical science while at the same time being slightly cautious concerning physiology's experimental future. ${ }^{9}$ A Bill was drafted by R. B. Litchfield (1832-1903), founder of the Working Men's College, who was the husband of Darwin's daughter Henrietta and adopted in Parliament, at the behest of Darwin and Burdon Sanderson, by Lyon Playfair (1818-98). There it would compete directly with Cobbe's rival Bill.

From the outset, Darwin's aim was clear. He personally sent the draft Bill to Playfair, who had already been given it by Burdon Sanderson, 'drawn up with the concurrence of some eminent physiologists' with the aim of serving 'to protect animals from needless suffering, \& will not prevent the future progress of physiology'. ${ }^{10}$ In this he was too sanguine. Playfair wanted a more 'humanitarian preamble' but told Darwin he had 'done a great service in the cause of humanity \& Science'. Still, he had doubts about Darwin's attempt to safeguard experiments without anaesthetics by having each experiment registered. He thought it an 'impossibility' to 'explain to the unscientific the probable advantage of

${ }^{7}$ Darwin to Huxley, 14 January 1875, Darwin Correspondence Project, Letter no. 9817, www.darwinproject.ac.uk/letter/DCP-LETT-9817.xml, accessed 26 March 2020.

${ }^{8}$ Huxley to Darwin, 22 January 1875. Life and Letters of Thomas Henry Huxley, ed. L. Huxley (New York: D. Appleton, 1901), I, 470.

${ }^{9}$ French, Antivivisection, 71.

${ }^{10}$ Darwin to Playfair [before 29 April 1875], Darwin Correspondence Project, Letter no. 9909, www.darwinproject.ac.uk/letter/DCP-LETT-9909.xml, accessed 26 March 2020; Playfair to Darwin, 29 April 1875, Darwin Correspondence Project, Letter no. 9956, www .darwinproject.ac.uk/letter/DCP-LETT-9956.xml, accessed 26 March 2020. 
any particular experiments'. ${ }^{11}$ Here, Playfair hit on what would become a perennial problem. Scientists would ultimately get around it by claiming that such things were beyond the public's ken and that they should put their trust in the good character and moral fibre of scientific men. In the context of the perceived need for legislation of this kind, the argument seemed moot.

It was just as well that there was a short clock in the parliamentary session, since those practically impacted by Darwin's Bill started to see the cracks in it. As Playfair made amendments to the Bill, Huxley and others became aware that they might by accident outlaw all vivisection for the purpose of demonstration in the course of teaching, which would directly hinder them in their own work. ${ }^{12}$ Men of science had risked legislating themselves into a corner. Burdon Sanderson, dismayed at the diversion of the Bill's language 'by men whose avowed object is the suppression of science' declared himself 'delighted' that 'compromise is at an end'. ${ }^{13}$ Having co-sponsored the initiative with Darwin, he withdrew. Playfair was embittered by the affair, but in the meantime the government had decided to appoint a Royal Commission on the matter, and Playfair at least attempted to ensure that physiologists would be represented among the Commissioners. ${ }^{14}$ The competing Bills were both dropped. Huxley received the news with resignation, telling Darwin that he had vowed never to 'be a member of another Commission if I could help it, but I suppose I shall have to serve on this'. ${ }^{15}$ And serve he did.

It was Huxley who personally requested that Darwin give testimony to the Commission, for a man of such influence was a great asset for the cause of science. The Commission reported in 1876. In many respects, the entire story of Humane Professions, encompassing not only England but Germany and the USA, pivots on the testimony given to the Commissioners and on the actions taken as a result of its inquiry, specifically the Cruelty to

${ }^{11}$ Playfair to Darwin, 15 May 1875, Darwin Correspondence Project, Letter no. 9980, www.darwinproject.ac.uk/letter/DCP-LETT-9980.xml, accessed 26 March 2020.

12 Playfair to Darwin, 26 May 1875, Darwin Correspondence Project, Letter no. 9994, www .darwinproject.ac.uk/letter/DCP-LETT-9994.xml, accessed 26 March 2020; Huxley to Darwin, 19 May 1875, Darwin Correspondence Project, Letter no. 9985, www .darwinproject.ac.uk/letter/DCP-LETT-9985.xml, accessed 26 March 2020; Sanderson to Darwin, 23 May 1875, Darwin Correspondence Project, Letter no. 9989A, www .darwinproject.ac.uk/letter/DCP-LETT-9989A.xml; accessed 26 March 2020.

13 Sanderson to Darwin, 23 May 1875, Darwin Correspondence Project, Letter no. 9989A, www.darwinproject.ac.uk/letter/DCP-LETT-9989A.xml, accessed 26 March 2020.

${ }^{14}$ Playfair to Darwin, 27 May 1875, Darwin Correspondence Project, Letter no. 9996, www.darwinproject.ac.uk/letter/DCP-LETT-9996.xml, accessed 26 March 2020. UK Parliament, Report of the Royal Commission on the Practice of Subjecting Live Animals to Experiments for Scientific Purposes, C. 1297 (1876), hereafter, Royal Commission on Vivisection.

${ }^{15}$ Huxley to Darwin, 5 June 1875, Life and Letters of Thomas Henry Huxley, I, 471. 
Animals Act of $1876 .{ }^{16}$ This Act combined previous legislation on animal cruelty with new clauses that regulated animal experimentation for the purposes of medical or scientific research. It forced researchers to apply for licences and certificates from the government, effectively making the government the moral arbiter of questions of laboratory ethics.

I do not want to offer another lengthy account of the contents of the Royal Commission. Others have done so. ${ }^{17} \mathrm{I}$ will have cause to make reference to it in one special aspect, namely the construction of German monstrousness in the testimony, and the effect of this particular construction for German research (see the next chapter). To take the thing as a whole, however, the Royal Commission stands as the first ad hoc expression of the defence of medical experimentation by the medical and scientific establishment. As we have seen, there was a concern, especially among the older generation of scientists who were called upon to testify, that some regulative measure ought to be taken for the sake of safeguarding animals from pain. The overwhelming majority of practising physiologists and others who had recourse to animal experimentation testified that anaesthetics were already in widespread use and that vivisection had not dimmed or otherwise diminished the humanity of the men who did it.

The final report of the Commission endorsed this view, but antivivisectionists led by Cobbe harried the government for legislation and found, in Lord Carnarvon, an ancient of the animal welfare movement, a more than willing ally. A Bill was introduced that appalled the scientific community, which was rallied by Ernest Hart (1835-98) at the British Medical fournal $(B M Y)$. In their supreme efforts to get the Bill amended, and amended with major concessions, they ended up providing tacit support for legislation that most had considered unnecessary after the Royal Commission. The Darwinian compromise had come to pass after all, but in an Act that was far more complex than had been anticipated in $1875 .{ }^{18}$ Philip Pye-Smith (1839-1914) wrote in Nature, 'The evidence on which Legislation was recommended went beyond the facts, the Report went beyond the evidence, and the recommendations beyond the Report, the Bill actually introduced ... did not so much exceed as contradict the recommendations of the Royal Commissioners. ${ }^{, 19}$ It seemed, for science, a mess. The upshot was an awakening: the need for organization. Darwin's foot soldiers would

$1639 \& 40$ Vic, c. 77 (1876).

17 Asha Hornsby, 'Unfeeling Brutes? The 1875 Royal Commission on Vivisection and the Science of Suffering', Victorian Review, 45 (2019): 97-115; French, Antivivisection, 79ff.

18 The events surrounding the passage of the 1876 Bill are gloriously described by French, Antivivisection, chapter 5 .

19 The letter is signed P.H.P.S. so is presumably by Philip Henry Pye-Smith, the physiologist specializing in the skin. The quote, when it is used, is usually not attributed and generally incorrect. Nature, 20 July 1876, 248. 
spend the rest of the century trying to undo the compromise Darwin had had a hand in making. Darwin, too, would ultimately come to see the Act as a step too far.

\section{Monkey Business}

Crowded into Gerald Yeo's (1845-1909) laboratory at King's College one autumn afternoon in 1881 was an astonishing collection of medical and scientific influence, eminence, intelligence and political weight. JeanMartin Charcot (1825-93) rubbed shoulders with Michael Foster. Friedrich Goltz (1834-1902) was there, alongside his Scottish rival David Ferrier (1843-1928). Ferrier's mentor, William Rutherford (1839-99), turned up, as did John Burdon Sanderson and William Carpenter (181385). T. H. Huxley, seemingly omnipresent at this stage of his career, was there too. Here was a crowd known to each other, deeply embedded in each other's lives, careers and labours. They represented the zenith of scientific and medical expertise, covering ground from clinical psychiatry to neurology to physiology to evolutionary biology. They were there to see a score settled. Were brain functions localized? Ferrier thought so. He had said as much to the International Medical Congress (IMC) that morning, directly gainsaying the conclusions drawn from the vivisection of a dog by Goltz. The dog was also present at Yeo's laboratory, as were two macaques.

The monkeys, despite the illustrious gathering, were the focus of attention. Yeo had removed parts of their brain in order to demonstrate localized function, despite having started out a sceptic of Ferrier's ideas. Charcot was moved to remark that they were like his patients back at the Salpêtrière. The living proof being insufficient, the animals were killed and their brains dispatched to more medical-scientific luminaries, Klein, Langley, Schäfer and Gowers, for dissection and examination. ${ }^{20}$ It was a career-defining moment for Ferrier and his science, but it was also the cause of personal trouble. The display, as well as the experiments that preceded it, became a flashpoint for the antivivisection movement and, in response, a motivating factor for the scientific and medical establishment in Britain to organize and institutionalize the defence of their methods, practices and rationale. Ferrier would be the first notable scientist to be prosecuted for cruelty to animals under the Act of Parliament that had been passed in $1876 .{ }^{21}$ His

${ }^{20}$ An account of the debate, the excursion to Yeo's laboratory and the study of the killed animals' brains is contained in Sir William Mac Cormac, ed., Transactions of the International Medical Congress Seventh Session (London: J. W. Kolckmann, 1881), 218-43.

21 There had been one prior trial, of Gustav Adolph Arbrath in 1876, but his prosecution was technical (advertising a public demonstration of the experiment, which in the end he 
trial followed on the heels of a Congress that had been defined by a significant effort to promote the value of vivisection for humanity, and to do so in the name of a Darwinian vision of biology, evolution and civilization. Indeed, Darwin himself was implicated at every stage and had been something of a figurehead in the preceding years, as the medical establishment attempted to mollify opposition through consultation and regulation. While Ferrier's acquittal led, in turn, to fundamental changes in the establishment's procedures in heading off antivivisectionist and anti-scientific activism, this was an activism that had been forged by Darwin's foot soldiers and often in Darwin's name. This was a group of men, eminent in their own right, who understood that it was Darwin's fame and Darwin's principles upon which the general principles of scientific progress were predicated. The first decades of the organized response to antivivisection were framed in these terms, for the first time unfolding the motivations of the medical and scientific communities, not as Darwinists in the technical sense, but as followers and friends (largely) of Darwin who shared a vision of scientific practice that Darwin helped create.

In this, the role of the Physiological Society has been rather underestimated. ${ }^{22}$ While its title seemed to link it to a particular specialism, such was the fluidity of scientific disciplinary boundaries (if such things even existed) that the members of the Physiological Society were made up of the great and good of biological and evolutionary science. Formed in March 1876 to protect the interests of physiologists, its first meeting at the home of John Burdon Sanderson included William Sharpey, T. H. Huxley (Darwin's 'Bulldog'), Michael Foster, George Henry Lewes (1817-78), Francis Galton (1822-1911) (Darwin's half cousin), John Marshall (181891), G. M. Humphry (1820-98), William Pavy (1829-1911), Thomas Lauder Brunton (1844-1916), David Ferrier, P. H. Pye-Smith, Walter Gaskell (1847-1914), J. G. McKendrick (1841-1926), Emanuel Klein (1844-1925), E. A. Schäfer (1850-1935), Francis Darwin (1848-1925) (Darwin's son), George John Romanes (1848-94) (Darwin's most ambitious disciple) and Gerald Yeo. The initial list of members was limited to forty men (later expanded to fifty) actively working as physiologists. The rules permitted up to five honorary members, and Charles Darwin himself was the first such. The society thus contained, from the first, Darwin, Darwin's family and his chief acolytes, as well as the majority of the most prominent medical researchers in the country. Obviously, with such ranks as

did not carry out) and did not resonate with the medical or scientific community. See French, Antivivisection, 201.

${ }^{22}$ French apparently did not consult Physiological Society records, concluding that in its early days 'the society qua society played little role in the activity' of combating antivivisection (Antivivisection, 196), breaking with silence as a policy only in 1881 . 
these, the medical community at large was within easy reach. In spring 1877, the Society started to investigate the working of the Act and found that certificates were being suspended and refused and that 'original scientific investigation' was being thwarted. A resolution was passed to submit a report of their investigation to the General Medical Council, apparently putting it in their hands. ${ }^{23}$ But by the end of 1877 , the Society was forming its own committee to report to the Home Secretary the 'effects of the impediments which have been thrown in the way of therapeutic experiment' by the Act. ${ }^{24}$ Brunton was charged with rounding up the President of the College of Physicians and the President of the General Medical Council on the official business of the Society to personally remove from the Home Secretary 'any misapprehension concerning the suspension of certificates' ${ }^{25}$ By early 1878 the Society had resolved to 'take such measures, by issuing publications or otherwise, as they may think fit, to counteract the anti-vivisection agitation now being carried on throughout the country, and that they [the committee] be authorized to incur such expense as may be necessary'. ${ }^{26}$ Direct access to the Home Secretary was immediately fruitful, with restrictions being lifted by such informal means. ${ }^{27}$ The Society began procuring and distributing pamphlets by eminent physiologists on the subjects of their research. ${ }^{28}$

While the scale of all this was initially small, it was prototypical, and it was in the planning stages of the IMC that the Society began to assume a larger role, which in part explains the increased attention on animal experimentation that the IMC brought about. Romanes, Darwin's most faithful and enthusiastic disciple, was charged, as secretary of the Society, first to communicate with European and American physiologists and cordially welcome them to London for the IMC, and subsequently to invite forty foreign physiologists, ensuring the embodiment of a pan-European argument for the human value of vivisection. The Society was to provide hospitality and lodgings. ${ }^{29}$ Romanes' letter (also signed by Gerald Yeo) expressed 'the hope

${ }^{23}$ Minutes of meeting on 10 May 1877, 31-2, Physiological Society Minute Book, 1876-92, SA/PHY/C/1/1, Wellcome Library, London.

24 Minutes of meeting on 13 December 1877, 34, Physiological Society Minute Book, 1876-92, SA/PHY/C/1/1, Wellcome Library, London.

${ }^{25}$ Minutes of meeting on 13 December 1877, 36, Physiological Society Minute Book, 1876-92, SA/PHY/C/1/1, Wellcome Library, London.

${ }^{26}$ Minutes of meeting on 10 January 1878, 36-7, Physiological Society Minute Book, 1876-92, SA/PHY/C/1/1, Wellcome Library, London.

27 Minutes of meeting on 14 February 1878, 38, Physiological Society Minute Book, 1876-92, SA/PHY/C/1/1, Wellcome Library, London.

${ }^{28}$ Minutes of meeting on 14 March 1878, 39, Physiological Society Minute Book, 1876-92, SA/PHY/C/1/1, Wellcome Library, London.

${ }^{29}$ Minutes of meeting on 14 October 1880, 56; 11 November 1880, 58; and 8 December 1880, 59, Physiological Society Minute Book, 1876-92, SA/PHY/C/1/1, Wellcome Library, London. 
of our Society that the Congress of 1881 will intensify by social intercourse the friendly feeling which already exists between foreign and English physiologists'. ${ }^{30}$ But the intent went beyond simple network building. ${ }^{31}$ The presentation of a powerful consensus was in the offing.

As the IMC approached, the Society adjusted its approach. Romanes introduced Ernest Hart, editor of the British Medical fournal, to the committee meeting of July 1881. Hart, in conjunction with Romanes' nudging on the matter, was 'desirous of making some suggestion touching the policy of the Society with reference to the agitation on vivisection'. ${ }^{32}$ $\mathrm{He}$ told them that physiologists had 'sufficiently long treated the accusations of the agitators with silence, and that it was now time to inform the public through the medium of the press what vivisection has done for physiology \& medicine' as well as what it would do for the 'progress of these sciences'. The Committee, after a lengthy discussion, first set itself on a more vigorous publishing footing, proposing to republish articles on the subject and preparing extracts from the Royal Commission for publication in book form, but determined instead to wait and capitalize on the forthcoming IMC and consult with their 'foreign guests' on further action, keeping Hart in communication with the Committee. ${ }^{33}$ The Physiological Society, in conjunction with the $B M \mathcal{F}$, essentially planned on instrumentalizing the IMC for the purposes of an organized defence of vivisection.

The consultation meeting took place on 5 August at St James' Hall, with the Society's Committee in full attendance, accompanied by an extraordinary array of twenty-two guests, including Goltz, Herbert Watney (1843-1932), Charles-Édouard Brown-Séquard (1817-94) and Henry P. Bowditch (1840-1911), who would come to play a major role in the defence of experimental medicine in the USA. At this meeting an international line of argument would be hashed out that would, essentially, outline the strategy against antivivisection wherever it might arise. The Physiological Society's resolution was read, to wit, 'that it would be desirable that a series of articles be published in a leading Review or magazine explaining the examples \& evidences of the progress of knowledge by the aid of experimental physiology, \& of the extent to which modern medicine

${ }^{30}$ Minutes of meeting on 9 December 1880, 60 and page facing 61, Physiological Society Minute Book, 1876-92, SA/PHY/C/1/1, Wellcome Library, London.

${ }^{31}$ I have written in great detail of Romanes' personal, private and professional activities as the early co-ordinator of the defence of vivisection in England. In lieu of repeating this detail here, see Rob Boddice, 'Vivisecting Major: A Victorian Gentleman Scientist Defends Animal Experimentation, 1876-1885', Isis, 102 (2011): 215-37.

32 Minutes of meeting on 9 July 1881, 67. Physiological Society Minute Book, 1876-92, $\mathrm{SA} / \mathrm{PHY} / \mathrm{C} / 1 / 1$, Wellcome Library, London.

${ }^{33}$ Minutes of meeting on 9 July $1881,68-9$. Physiological Society Minute Book, 1876-92, $\mathrm{SA} / \mathrm{PHY} / \mathrm{C} / 1 / 1$, Wellcome Library, London. 
is likely to be benefitted by physiological and pathological research.${ }^{34}$ The Nineteenth Century was the Society's magazine of choice, and Romanes was instructed (through his own instigation) to contact such men as James Paget (1814-99), William Gull (1816-90), Charles Darwin, Thomas Huxley, Joseph Lister (1827-1912), among others, to write the articles.

Romanes sought out Darwin as a matter of priority, suggesting he write about the 'Mistaken humanity of the agitation: real humanity of vivisection', but badly misjudged the man. Darwin's support of the physiologists was unwavering, but he was constitutionally incapable of willingly entering personally into a controversy (again). He acknowledged that he had a 'duty' to express himself publicly on the matter, and wished for his name to 'appear with others in the same cause', but felt that he could not overcome his 'mental paralysis' to write anything 'careful and accurate' regarding physiology's achievements 'for man'. He begged Romanes to quote his letter to The Times in April that year, permitting Romanes to say that Darwin still abided 'most strongly in [his] expressed conviction' in favour of the physiologists. But he refused Romanes' request to 'stand among this noble army of martyrs' by writing anything new. ${ }^{35}$

Romanes turned instead to Richard Owen (1804-92), who complied, as did James Paget and Samuel Wilks (1824-1911). Under the editorial stewardship of Philip Pye-Smith, three articles appeared under the common title 'Vivisection: Its Pains and Its Uses'. Owen, though quite opposed to Darwinists in many respects, was animated by a concern about the status of scientists as respectable, honourable men. His essay dwelt on antivivisectionism's 'unproven and umerited stigma on scientific men', those 'choicest intellects' that 'add to the power of the beneficent healer, as applied to the prevention, alleviation, or removal of human suffering. ${ }^{36}$ Wilks and Paget, thus drawn into the controversy, would go on to play a major role in the defence of medical research. Other key figures in the Physiological Society would follow with their own, carefully placed, articles to inform the public of the humanitarian benefits of vivisection. ${ }^{37}$ The IMC would prove to be the short fuse that helped formalize that defence.

${ }^{34}$ Minutes of meeting on 5 August 1881, 70-71. Physiological Society Minute Book, 1876-92, SA/PHY/C/1/1, Wellcome Library, London.

35 Romanes to Darwin, 31 August 1881, The Life and Letters of George fohn Romanes, ed. E. Romanes, 2nd edn (London: Longmans, Green, 1896), 123. Darwin to Romanes, 2 September 1881, Life and Letters of George fohn Romanes, ed. E. Romanes, 124. 'Mr. Darwin on Vivisection', The Times, 18 April 1881 (and see below).

${ }^{36}$ James Paget, Richard Owen and Samuel Wilks, 'Vivisection: Its Pains and Its Uses', Nineteenth Century, 10 (1881): 934-5.

37 Thomas Lauder Brunton, 'Vivisection and the Use of Remedies', Nineteenth Century, 11 (1882): 479-87; Gerald F. Yeo, 'The Practice of Vivisection in England', Fortnightly Review, 31:183 (1882): 352-68; William W. Gull, 'The Ethics of Vivisection', Nineteenth Century, 11:61 (1882): 456-67. Brunton, for example, concluded by stating that 
To give a sense of scale of the IMC, examine the extraordinary composite photograph, produced in 1882 by Herbert R. Barraud, of the delegates (Figure 1.1). It includes 695 full-length portraits, for which there is also a key. The assemblage is a veritable who's who of the medical world in 1881. The keen eye will be able to pick out Lord Lister, T. H. Huxley, Rudolf Virchow (1821-1902), J-M. Charcot, Joseph Hooker (1817-1911), John Burdon Sanderson, William Jenner (1815-98), David Ferrier, William Osler (1849-1919), among the stars of the medical-scientific elite. The picture captures the gender and class dimension of the vivisection controversy quite neatly. Here are nearly 700 white men, ranging from the upper-middle-class professional and educated elite to the old guard of aristocratic and independent gentlemen of science. National origins seem of little consequence against this overwhelming homogeneity, which meant that science was implicitly being promoted as an act of male industry and effort. The appearance was given substance by the speeches made at the Congress, which supported or fed off contemporary evolutionary notions of men being the intellectual, active and creative sex of the human species, with emotions under the control of the will and the mind. They expressed an almost universal acclaim for the humanitarian benefits of animal experimentation (some of the distinctions in fine will be discussed below), which were opposed, at the IMC certainly, but more generally across two generations of public rhetoric on the matter, to the unrestrained emotionality and untrained, unschooled and undisciplined minds of women - even, and perhaps especially, those well-to-do women whose status afforded them the opportunity to speak what were assumed to be vapid minds.

The IMC, in the context of which the exhibition of Yeo's monkeys had come about, had, itself, been a signal moment for the medical and scientific communities in reaching a consensus about its position regarding vivisection. ${ }^{38}$ A number of speakers took the opportunity to extol the humanity of experimental methods, which, coupled with the movement behind the scenes of Romanes and the Physiological Society, created an

'practically every important addition since 1864 to the remedies used to prolong human life and alleviate human suffering has been made by the help of experiments', continuing, 'it is surely not wonderful that we, who have the serious duty of meeting the demands of suffering humanity, should unanimously demand that competent men shall not be hindered in forwarding the progress of the healing art by one of its most indispensable means' (487).

${ }^{38}$ The coverage in the British Medical fournal captured many of the significant speeches. A complete record of attendees and their abstracts, with the exception of the physiological section, can be found in Mac Cormac, International Medical Congress. The physiological section was organized in such a way as to make it impossible to include abstracts in advance, focusing instead on discussion of 'important and general topics' to which papers could then be appended. Afternoon sessions were given over to demonstrations (vol. $1,27)$. 


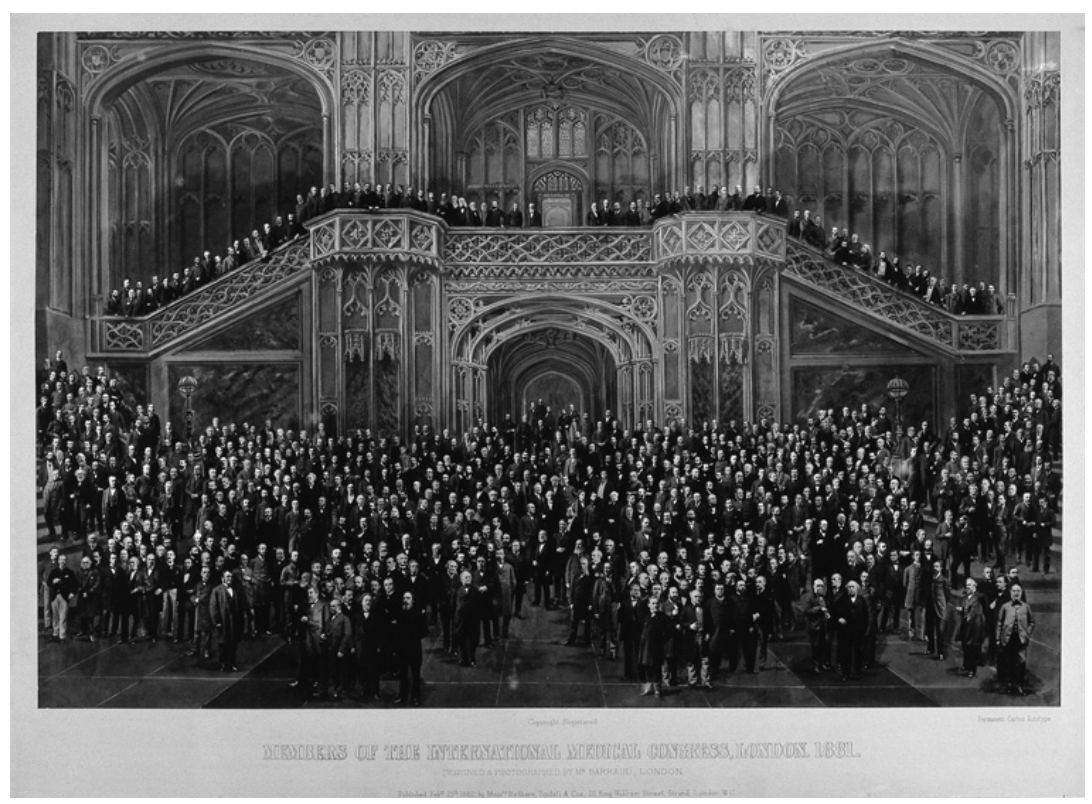

Figure 1.1 Members of the International Medical Congress, 1881. Composite photograph (1882). Wellcome Library, London. Attribution 4.0 International (CC BY 4.0).

impression of opinion in concert about the virtues of vivisection. I will have cause in the next chapter to come back to the speech of Rudolf Virchow at this event, but for now I will focus attention on a single speech, that of John Simon (1816-1904).

Simon is an important figure in this story. He was a pathologist, and conducted experiments on animals in that capacity, but by 1881 he had effectively taken charge of the government's public-health machinery. He had become the nation's first Chief Medical Officer in 1855, under the auspices of the General Board of Health, before a comparative boost in power, retaining his title as CMO in the Privy Council. He oversaw such things as the introduction of compulsory smallpox vaccination and had, as a professional role, the welfare of the whole population to consider. His organization of the institution of public health in a political capacity, as well as his endeavours to deliver public-health policies, are considered as major planks on the road to socialized medicine and, ultimately, to the formation of a national health service. His remit therefore also included medical research, and his name had come up fairly frequently during the 
first Royal Commission, to which he also gave evidence. In his capacity as $\mathrm{CMO}$, he had funds of some $£ 2000$ annually to disperse on scientific investigations to better understand the causes of diseases in order to aid in their prevention. It was his job, as he saw it, to advise the public about the nature of diseases and how to avoid them. What he knew came from experimentation. So, while not all of this government money went on vivisection, Simon was still one of the nation's major funders, on behalf of the Crown, for those who wished to experiment on animals. John Burdon Sanderson was a chief beneficiary, and under him, Drs Klein, Creighton and Baxter. The relation to Klein, about whom more in the next chapter, would prove problematic, but when explicitly pressed on the question of the 'hardening effect' on character of performing animal experiments, Simon was confident that the men he funded were not adversely affected. He was asked, by Hutton, if the 'habit of regarding animals as a mere battery of vital forces on which particular results are to be studied, necessarily to a certain extent produces the effect of diminishing the sympathy with their sufferings', and answered firmly in the negative, noting that he did 'not anywhere know a kinder person than Dr. Sanderson'. ${ }^{39}$ When the IMC came around, and Simon was given the role of opening the Section on Public Medicine, it was an ideal platform to make a broad case for the humanity of vivisection. He made that case with a lengthy lecture delivered with his colleagues in mind, but with the general public in view. ${ }^{40}$

Simon cautioned his audience that 'the general public overhears what we say' and, more generously than most of his colleagues, thought that 'the laity can follow equally with ourselves'. It was for the laity, therefore, that he set out his vision of the 'scientific method of State Medicine'. Even the concept of 'State Medicine' presupposed 'a special class of persons whom the unskilled general public can identify as presumably possessing the required knowledge' to inform the 'BodyPolitic' that concerns itself 'with the health-interests of the people'. Its chief focus was on prevention of disease, and in the name of that cause Simon defended the right of the State to intervene and limit 'the freedom of persons and property' where the common health of the nation was at stake. In his view, 'disease can only be prevented by those who have knowledge of its causes', and there was no other method for the study of causes in the physical and biological sciences that 'that which consists in experiment'. Simon identified two options in this regard:

39 Royal Commission on Vivisection (1876), 68-75.

${ }^{40}$ For more on Simon, see his English Sanitary Institutions, 2nd edn (London: John Murray, 1897). See also R. Lambert, Sir Fohn Simon, 1816-1904 and English Social Administration (London: MacGibbon \& Kee, 1963). 
limited and controlled experiments on animals performed in the laboratory, and experiments 'which accident does for us' on humans and other animals, without control, and with a heavy cost of human and animal suffering. The former, which had progressed more 'in these twenty-five years than in the twenty-five centuries which preceded them', were offering 'larger and larger vistas of hope' through 'daily increments of knowledge ... a new world of strange knowledge'. Some of this 'abstract scientific knowledge', he said, was already 'passing into preventive and curative act', which was 'the same sort of boon' for mankind as Jenner's employment of vaccination in combating smallpox. He did not stint on praising the men, many of them in the room, who had made their age the very pinnacle and promise of civilization:

I venture to say that in the records of human industry it would be impossible to point to work of more promise to the world than these various contributions to the knowledge of disease, and of its cure and prevention; and they are contributions which from the nature of the case have come, and could only have come, from the performance of experiments on living animals ... at the cost of relatively insignificant quantities of brute suffering ... to create an infinity of new resources of relief for the sufferings both of brute and man.

Against this lay the Act of 1876, which 'virtually confounds together that imaginary class of unqualified and cruel persons, and ... our professional class of bonâ fide scientific investigators'. In Simon's view, the names of these men should have been 'sufficient security for their conduct', but instead the minute scrutiny of the Secretary of State - a politician of no scientific training - was 'substituted for the discretion and conscience of the scientific investigator'. Simon could scarcely credit this lack of trust, in a profession that had been regarded, 'from time immemorial', with 'the almost unbounded trust' of the world. Simon forecast that the Act would have to be altered and, in considering the moral aspect of vivisection, begged leave to make a 'public confession of faith'. Examining his own conscience, he said he did 'not in any degree regard it as a matter of indifference that, in certain cases, by my own hand or by that of some one acting for me, I must inflict death or pain on any living thing. I, on the contrary, think of it with true compunction; but I think of it as good or bad according to the end which it subserves'. Motive counted for everything:

Where I see my way to acquire, at that painful cost, the kind of exact knowledge which, either in itself or in contribution to our common stock, will promote the cure or prevention of disease in the race to which the animal belongs, or in the animal kingdom generally, or (above all) in the race of man, I no more flinch from what then seems to me a professional duty, though a painful one, than I would, in the days before chloroform, have shrunk from the cries of a child whom I had to cut for stone. 
This broader, beneficent motive, this desire to save the many at the cost of a few, was too often overlooked, and Simon objected and protested against 'a standard of right and wrong being fixed for us on grounds which are merely sentimental'. He complained of the mobilization of 'an emotion' against vivisection that had nothing to do with what actually occurred in animal experimentation and took no stock of its motives. $\mathrm{He}$ felt that against such people, with such emotions, 'our profession cannot seriously argue. Our own verb of life', he said, 'is $\varepsilon \rho \gamma \alpha \zeta \varepsilon \sigma \theta \alpha l$ [to work], not $\alpha l \sigma \theta \alpha v \varepsilon \sigma \theta \alpha l$ [to feel]'. Here was the signal note, the defining motif of the medical establishment: a professionalized, restrained, diligent intelligence applied to medical problems in the name of relieving suffering, but, necessarily aloof from the aesthetics of suffering in the laboratory. What it looked like and sounded like was everything to the antivivisectionists, but nothing to such men as he addressed, who knew better. To them, to their 'standard of right and wrong', these 'lackadaisical aesthetics may seem but a feeble form of sensuality'. Against 'the mere screamers and agitation-mongers who, happy in their hysterics or their hire, go about day by day calumniating our profession' he harboured a bitter contempt. He expressed, against such people, a hope in education, and in the making of a population that would see State Medicine as representative of the 'true ideal of Government-action which sets its standard of success in the "greatest happiness of the greatest number", ${ }^{41}$

It was an extraordinary speech, coming from within the worlds of both medicine and politics, and aimed specifically to reach the ear of the discerning layman. The speech was published in full in the $B M \mathcal{F}$, capturing the tone of a medical profession increasingly alive to the challenge presented by antivivisectionists and of the necessity to strike an attitude and adopt practical measures to defend against them. If Simon tapped the spirit of the assembled company at the IMC, it fell to Romanes, in his final job with regard to IMC business, to prepare a resolution on vivisection, at the behest of the Physiological Section of the Congress, to be read before a general meeting at the close of the event. It was to give the IMC a post-facto purpose. The resolution, which encapsulated Simon's argument, read as follows: 'That this Congress records its conviction that experiments on living animals have proved of the utmost service to medicine in the past, and are indispensable to its future progress. That, accordingly, while strongly deprecating the infliction of unnecessary pain, it is of opinion, alike in the interests of man and of animals, that it is not desirable to restrict competent persons in the

${ }^{41}$ John Simon, 'An Address Delivered at the Opening of the Section of Public Medicine', British Medical fournal, 6 August 1881, 219-23. 
performance of such experiments. ${ }^{42}$ With unanimous approval and a loud ovation, the resolution was passed. The world's medical establishment set out its stall in favour of vivisection as a humane practice.

\section{Darwin's Regret?}

The Association for the Advancement of Medicine by Research (AAMR) was established in 1882. The process of its establishment has been tacitly assumed to have been a coordinated and conscious strategic effort of the scientific and medical communities to structure its defence of medical research. Its activity is usually summarized as that of an advisory body, assisting the government with the adjudication of applications to conduct research by animal experimentation. In this way, the AAMR introduced a formal entanglement of loosely connected medical-scientific interests with government operations, acting as a private bulwark against an overly conservative interpretation of the 1876 Act of Parliament, and ensuring that the vast majority of planned research using animals was allowed to proceed.

There is something a bit too neat in this general reading, in part because it overlooks the way in which the AAMR came into existence. For this we must return to David Ferrier and the demonstration carried out in eminent company during the IMC. It was because of this that Ferrier would be singled out. Frances Power Cobbe's Victoria Street Society, the most strident of the antivivisectionist groups, had prosecuted Ferrier for cruelty to animals under the terms of the 1876 Act. The proceeding was a farce that ultimately damaged the credibility of the activists as well as strengthening the hand of the medical establishment. ${ }^{43}$ Ferrier's debate with Goltz about the localization of functions in the brain had caused the delegation of men to take their leave from the IMC and head to Gerald Yeo's laboratory at King's College. It was Yeo who kept the two monkeys that had been operated on under his licence, and kept alive so as to test the relation of movement and sensation to parts of the surface of the brain. Based on a confused account of Ferrier's lecture and an assumption that it had been Ferrier who had carried out the experiments on the exhibited monkeys, as well as a further assumption that there was no licence to keep the animals alive after anaesthesia had worn off, Ferrier had been brought to book. The transcript of the trial, reproduced in the $B M \mathcal{F}$, shows that the prosecution was disorganized and

${ }^{42}$ British Medical Fournal, 13 August 1881, 301. E. Romanes, ed., The Life and Letters of George fohn Romanes, 126.

${ }^{43}$ On Ferrier's trial, see French, Antivivisection, 200-203; Laura Otis, "'Howled out of the Country": Wilkie Collins and H.G. Wells Retry David Ferrier', in Neurology and Literature, 1860-1920, ed. Anne Stiles (Houndmills, UK: Palgrave, 2007); Cathy Gere, Pain, Pleasure, 150-60. 
ill informed and the summons was quickly dismissed. No laws had been broken. ${ }^{44}$

As French details, prominent antivivisectionists such as Frances Power Cobbe saw Ferrier's acquittal as proof of the unworkability of the law, and set about an even more ardent campaign. But French is too generous in saying that Ferrier's trial was a 'potent publicity tool' for the antivivisectionists. ${ }^{45}$ Whatever rhetoric Cobbe attached to the dismissal of the case, the evident truth was that the Victoria Street Society had misjudged their opportunity, overplayed their hand and been easily undone in the Bow Street Court. Although Cobbe protested that the Act was futile, it was actually an effect of the prosecution that would make it so. The attention it brought about caused the scientific community to reflect that generalized statements of the value of experimentation, such as Romanes' resolution at the IMC, were not sufficiently effective. A great outpouring of support had been occasioned by the public knowledge of Ferrier's prosecution, which began in November 1881, with a call for donations to support any financial burden that the trial might occasion. In the event, the British Medical Association met Ferrier's costs. The rapid dismissal of the case then led to further calls for donations for Ferrier, but with the intention shifted towards a testimonial.

It is important to set straight the chronology of what happened next, especially since French notes as effects of the Ferrier trial a call in the Fournal of Science for a 'Biological Defence League' and the Lancet's call for a concerted agitation among the medical and scientific establishment for public education on the humanity and beneficence of vivisection. While the Fournal of Science did make such a call in December 1881, it was, at that point, a renewal of a call for such a 'League' that had been made as early as June 1880 . On that occasion, the editors remarked upon the 'strange amount of apathy on the question'. ${ }^{46}$ Similarly, the Lancet call for scientists to 'agitate! Agitate! Agitate!' was made in August 1881, after the IMC but before Ferrier's trial. So, who or what was the specific agent that broke the apathy and diverted the attention of the whole medical community towards the formation of a new association?

It was Samuel Wilks, the eminent physician, and one of Romanes' Nineteenth Century writers, who suggested (given that the Ferrier case was over) that the monies being collected for a testimonial to Ferrier would be

44 'The Charge against Professor Ferrier under the Vivisection Act: Dismissal of the Summons', BMF, 19 November 1881, 836-42.

${ }^{45}$ French, Antivivisection, 202.

${ }^{46}$ French, Antivivisection, 203; M.D., 'The Protection of Research', Fournal of Science, June 1880, 408; Lancet, 20 August 1881, 343-4; 'The Recent Vivisection Case', Fournal of Science, December 1881, 733. 
better applied to the formation of a 'Science Defence Association', to protect the whole community from such attacks from the antivivisectionists. ${ }^{47}$ The renewed and ardent call for a 'Biological Defence League' followed, but it was Wilks' call that prompted action, and while French notes that the 'Physiological Society was clearly out of its depth in dealing with a challenge of this type', it was in fact the Physiological Society that facilitated the formal institutionalization of the defence of research among the scientific and medical communities at large. The Society, and Gerald Yeo in particular, was charged with administering the list of subscribers and monies donated. There is something rather fitting in this, given that Yeo's monkeys had occasioned the trouble in the first place. Thomas Lauder Brunton was instructed to write to Charles Darwin to ask him to become President of the new Association. Darwin declined on the basis of his health, partly, but offered a measure of support for the enterprise that was suggestive of regret. The tactics of the antivivisectionists in using the 1876 Act to bring a scientists to trial were seen as insidious. His attempt at legislative compromise, on reflection, had been a mistake. Such had been clear earlier in the year, when Darwin had expressed his views in The Times.

That piece - a reproduction of a letter addressed to Professor Holmgren of Uppsala giving his full opinion on 'the right of experimenting on living animals' - indicated that the whole saga of 1875-6 had been a mistake. Darwin confessed that he had been 'led to think that it might be advisable to have an Act of Parliament' to address the assertion 'that inhumanity was here practised and useless suffering caused to animals', to remove 'all just cause of complaint' while leaving 'physiologists free to pursue their researches'. Bitterly, he noted that the 1876 Act was 'very different' to the Bill he had had in mind. The Royal Commission, he said, had 'proved that the accusations made against our English physiologists were false', and he knew 'that physiology cannot possibly progress except by means of experiments on living animals'. Darwin expressed 'the deepest conviction that he who retards the progress of physiology commits a crime against mankind'. Perhaps, on reflection, Darwin felt he had played a part in such a 'crime'. Looking forward, he opined that 'no one, unless he is grossly ignorant of what science has done for mankind, can entertain any doubt of the incalculable benefits which will hereafter be derived from physiology, not only by man, but by the lower animals'. Darwin praised Virchow, as an example of a researcher who had saved 'many lives' and a 'fearful

${ }^{47}$ Samuel Wilks, 'A Science Defence Association', BMF, 26 November 1881, 878. Some of the pieces of this empirical puzzle were facilitated by Kristin Halverson, 'Physiological Cruelty? Discussing and Developing Vivisection in Great Britain, 1875-1901', MA thesis, Södertörn University (2016), 59. 
amount of suffering' and forecast that 'In the future every one will be astonished at the ingratitude shown, at least in England, to these benefactors of mankind'. Darwin committed himself to honour, always, 'every one who advances the noble science of physiology'. ${ }^{48}$

In that letter, however, Darwin had intimated that it was for physiologists alone to make specific claims about the humanitarian benefits of their research, concerning which Darwin was only an amateur. For this reason he had declined Romanes' invitation to write for the Nineteenth Century, instead referring Romanes to this letter. He now refused Lauder Brunton's invitation on the same grounds. He did not feel qualified to meet questions on medical topics, especially relating to physiological experiments, which he supported but did not carry out himself. It was not for him to be the figurehead of the movement. Around this time, Pye-Smith also tried again, and failed, to persuade Darwin to write a piece for the Nineteenth Century. ${ }^{49}$ Darwin had already pledged twenty guineas to help Ferrier, but now offered $£ 100$ to become a life member of the new Association, suggesting that the President of the College of Physicians would be a better bet to lead it. This was in December $1881 .^{50}$ By April of the following year, this Association, now flying under the banner of the Association for the Advancement of Medicine by Research, had been founded and constituted. Following Darwin's suggestion, the Presidency was shared between the Presidents of the Royal College of Physicians and the Royal College of Surgeons. Darwin had died the day before the AAMR's first meeting and was celebrated in the minutes as a 'munificent subscriber to its funds'. ${ }^{51}$ When the AAMR published its first list of subscribers in the $B M Y$, the late Darwin topped the list (not in terms of the amount given, but in terms of prestige). Darwin's $£ 100$ was topped by Bowman's $£ 105$, and matched by Sir William Gull and Sir Erasmus Wilson, while other luminaries such as Lister subscribed $£ 50$, William Jenner put in $£ 52 / 10 / 0$, the same amount as James Paget. These represent considerable investments and commitments, with the first fifty-two subscribers to the Association giving a total of $£ 1138$ / $3 / 0 .^{52}$ Subscriptions and donations continued to arrive, such that, despite a heavy expenditure on research, printing, letter campaigning and

48 'Mr. Darwin on Vivisection', The Times, 18 April 1881.

49 Pye-Smith to Darwin, 19 December 1881, Darwin Correspondence Project, 'Letter no. 13566', www.darwinproject.ac.uk/letter/DCP-LETT-13566.xml, accessed 6 May 2020.

${ }^{50}$ Darwin to Lauder Brunton, 22 November 1881 and 17 December 1881, Francis Darwin and A. C. Seward, eds, More Letters of Charles Darwin (London: John Murray), ii, 439.

51 AAMR Minute of 20 April 1882, Minutes of the Council and Executive, 4, MS.5310, Wellcome Library, London.

52 BMF, 1:1114 (6 May 1882): 679. Pye-Smith had invited Darwin to the meeting. PyeSmith to Darwin, 18 March 1882, Darwin Correspondence Project, 'Letter no. 13729', www.darwinproject.ac.uk/letter/DCP-LETT-13729.xml, accessed 6 May 2020. 
publishing, the Committee could actively invest $£ 1000$ by the beginning of January $1883 .{ }^{53}$ The organized response to antivivisection was in far better financial shape than any of its opponents.

The direct line of events, from the over-zealous prosecution of Ferrier to the establishment of the AAMR, suggests that a major coordinated movement among the scientific and medical community had been occasioned by the antivivisectionists overplaying their hand. Their prosecution of Ferrier was miscalculated, based on a misunderstanding of scientific collaboration, the very meaning of the word 'experiment' (which was debated somewhat during the case), the operating terms of the Act, and the specific allowances of the licensing system. It did no substantial harm to any individual (though Ferrier himself was somewhat rattled by it), and in fact only strengthened both the cause and the fame of English medical research. Ferrier's victory over Goltz was something of a red-letter day. Yet ineffective as the prosecution was, it stirred the community to ask, in sympathy with Ferrier, what if this happened to another of us? It prompted them to organize on a much grander scale than the Physiological Society (though it could scarcely have come about without the existence of the Physiological Society) with the specific aim of protecting scientific research by means of experiment on animals in a whole range of scientific and medical disciplines. Moreover, it sought sympathetic and financial support from the professional community at large, whether or not they actively participated in animal experimentation, on the basis that medical and scientific knowledge, and the general state of humanity, depended upon this kind of work. Unwittingly, the antivivisectionists had sparked, for the first time, a concerted effort at large-scale organization for the defence of science, with sufficient force that individuals were willing to contribute to the funding of a new strategic organization.

The AAMR may have set out with education and public opinion in mind, but it very quickly became a shrewd, secretive and political pseudogovernment agency. It rapidly went beyond an institutionalized lobby group, instead becoming intrinsically involved in the administration of the 1876 Act, to the great advantage of medical researchers. French argued as much in his 1975 book, but he had not seen the AAMR's own records, which are remarkable as a display of medical-scientific influence and authority. Despite the obvious conflict of interest, successive Home Secretaries signed over authority to a body of experts whose chief interest lay in administering the law with the least possible friction. As such, animal experimentation, curtailed for the five years after the Act, exploded in the

53 AAMR Minute of 4 January 1883, Minutes of the Council and Executive, 22, MS.5310, Wellcome Library, London. 
decades up to the First World War. Since French's account, which views both the Physiological Society and the AAMR through memoirs and Home Office records alone, and therefore obliquely, hardly anybody seems to have thought it necessary to appraise the narrative from the point of view of the medical establishment by actually consulting the records in question. The AAMR, for a well-funded and powerful organization of the medical community that actually administered the law, has received remarkably little attention since French, and then only to parrot what French originally wrote (whether he is cited or not). ${ }^{54}$ While I do not intend any major revision of French's narrative, it does seem that we are missing an account of the AAMR from the inside.

The first Council and Executive Committee of the AAMR comprised nominees put forward respectively by the President of the Royal College of Physicians and by the President of the Royal College of Surgeons. Darwin's demise may have robbed the Association of a figurehead, but in his stead it could still boast the active participation of men like Huxley, Lister, Burdon Sanderson, William Jenner, Joseph Hooker and James Paget, who served as chair. It is an astonishing list, considering the influence it cast over evolutionists, botanists, surgeons, physicians, physiologists, neurologists and more.

Having formed, it immediately set about inquiries concerning the nature of its defence against antivivisection. The existing literature concerning the AAMR would suggest that it began as an organ for the influence of public opinion that gradually withdrew from public life as its influence at the level of

${ }^{54}$ The exception is Shira Dina Shmuely, 'The Bureaucracy of Empathy: Vivisection and the Question of Animal Pain in Britain, 1876-1912', PhD thesis, Massachusetts Institute of Technology (2017); for the rule, Nicolaas Rupke, 'Pro-vivisection in England in the Early 1880s: Arguments and Motives', in Vivisection in Historical Perspective, ed. Nicolaas Rupke (London: Croom Helm, 1987), 189-93, argues that the IMC was the origin of organized pro-vivisection, and while he references the AAMR records at the Wellcome, he does not extensively draw upon them, following French; Otis, 'Howled out of the Country', 42; Dan Lyons, 'Protecting Animals versus the Pursuit of Knowledge: The Evolution of the British Animal Research Policy Process', Society E Animals, 19 (2011): 359; E. M. Tansey, “The Queen Has Been Dreadfully Shocked”: Aspects of Teaching Experimental Physiology Using Animals in Britain, 1876-1986', Advances in Physiology Education, 19 (1998): 24; Susan Hamilton, 'Reading and the Popular Critique of Science in the Victorian Anti-Vivisection Press: Frances Power Cobbe's Writing for the Victoria Street Society', Victorian Review, 36 (2010): 77, 78n6; David A. H. Wilson, 'The Public Relations of Experimental Animal Psychology in Britain in the 1970s', Contemporary British History, 18 (2004): 29; E. M. Tansey, 'The Wellcome Physiological Research Laboratories 1894-1904: The Home Office, Pharmaceutical Firms, and Animal Experiments', Medical History, 33 (1989): 22n127; A. W. H. Bates, Anti-Vivisection and the Profession of Medicine in Britain (London: Palgrave, 2017), 135, reduces the AAMR to a passing mention while noting that the number of experiments carried out in Britain had soared in the period between 1876 and 1906. The oversight robs him of an explanation. 
government grew stronger. This is not correct. Its founding Memorandum, published in 1882, indicates as much. The core of its argument lay in the following lines:

it is on the scientific investigator himself that the responsibility must ultimately rest of determining what is the best method of accomplishing a given scientific result, and by what means the greatest possible result may be obtained at the least possible cost of suffering. If restrictions are supposed to be necessary to control the conduct of careless individuals, let them be continued; but so long as scientific men exercise their responsibility in the humane spirit which has hitherto guided investigation in this country, they have a right to ask that no unnecessary obstacles should be placed in their way.

This amounted to demanding legislative change or at least access to the functioning of the Act, and the Memorandum did go on to express a hope that the views of the AAMR could be expressed in Parliament, in order both to rid the country of 'ill-advised attempts to totally abolish one of the most important methods of natural knowledge, and an indispensable method for the improvement of medicine' and to 'strengthen the hands of Government in administering the law, so as not to interfere with the just claims of science and with the paramount claims of human suffering' ${ }^{55}$ Such political intent was carried through in the AAMR's internal functioning.

At the first meeting of the Executive Committee, on 2 May 1882, two sub-committees were formed. The purpose of the first was to find the best 'mode' of promoting research, and it comprised Thomas Lauder Brunton, Michael Foster, Joseph Lister, Dr Payne, Pye-Smith, John Burdon Sanderson and Gerald Yeo. It was the most eminent circle of medical scientists. They specifically set out to find ways to promote research in physiology, pathology and therapeutics, agreeing that the chief way to do this was to 'remove existing practical difficulties', by which they referred to the problem of government licensing under the 1876 Act. To that end, they recommended that the Executive Committee should 'take cognizance of applications for licences and certificates ... and should accordingly put itself in communication with the persons authorized to sign certificates' and to ask such officials to join the committee of the AAMR. The sub-committee report was adopted by 24 May and a letter sent to the Home Secretary signed by William Jenner, James Paget and P. H. Pye-Smith. From the very first moment, therefore, the AAMR saw itself primarily as a political and administrative body, self-authorized to appropriate the practical operation of the law for the benefit of medical

55 Association for the Advancement of Medicine by Research, Memorandum of Facts and Considerations Relating to the Practice of Scientific Experiments on Living Animals, Commonly Called Vivisection (1882), 14. 
science. As an opening gambit, such a will to interfere in government business, concerning an Act that had been and which remained so politically charged, was audacious. Yet perhaps even the eminent sub-committee could not have imagined how well this approach would work for them.

A second sub-committee, with only three members and far less eminence, was charged with preparing lists of papers 'for reprinting and distribution', and this would be the visible sign of the AAMR in public life. Shortly afterwards, individual committee members were given specific roles concerning communication with the medical media: Brunton 'undertook the supervision and control of communications to be given to the British Medical Fournal'; Gerald Yeo took on the same role with respect to the Lancet; and Pye-Smith the same for 'other medical papers'. The messaging was to be controlled, uniform and, for the first time, a representative voice of the whole medical-scientific community. Yeo himself went into print pseudonymously, publishing Physiological Cruelty in 1883 - a landmark text that defenders would draw on for years. ${ }^{56}$ But the thrust, from the beginning, both in terms of investment of money and of minds, was to make the law work for science, behind the scenes. By 6 June, the AAMR had their reply from the Home Office.

The Home Secretary apparently jumped at the chance to avail himself of expert advice and assistance 'in administering the powers conferred upon him in the matter of the performing of experiments on living animals under the Act', soliciting AAMR views on the working of the Act and of the ways in which they would have it amended. After taking personal meetings, the form of this advice and assistance was to be stunning in its scope, a veritable coup for the scientists, and a hidden ace against all of the public antivivisectionist noise. The Home Secretary proposed that 'no application to him under the Act ... be entertained unless it has been recommended to him by the Council for the Association for the Advancement of Medicine Research'. In practical terms, this meant that all applications for licences to perform animal experiments were to be 'sent from the Home Office to you [PyeSmith] at your private address ... with a view to their being laid by you before the Council'. By December 1882, therefore, the AAMR had become a de facto agent of the government, in charge of both fielding and recommending licence applications, with the Home Office transforming its own

56 Philanthropos [Gerald Yeo], Physiological Cruelty; or, Fact v. Fancy: An Inquiry into the Vivisection Question (London: Tinsley, 1883). Yeo offered 300 copies of 'his book' to the AAMR in lieu of paying his subscription that year. AAMR Minute book, 45. Romanes was one of its most praiseworthy reviewers, lauding its author as 'something more (and may we not say something better?) than a man of science and a logician. He is clearly a man of large and generous heart, of finely strung feelings, and a lover of animals as well as a "lover of men"'. George John Romanes, 'Physiological Cruelty', Nature, 28 (1883): 537-8. 
role from that of official adjudicator on experimental science to that of rubber stamp.

The arrangement, which had been properly fleshed out by January 1883 , did not prevent the AAMR from promoting experimental medicine in other ways and nor did it oblige AAMR members to recuse themselves from recommending the granting of licences for which they were the applicants. Indeed, the AAMR's stated role was to make 'practical suggestions' on applications for the sake of removing delays in the system. Applications could arise from within the AAMR membership, be passed to the AAMR for expert approval or revision before approval, and then sent back to the Home Office for granting. For example, an early application under this scheme came from Heneage Gibbes, who had studied under Emanuel Klein, but the co-signers of the application were John Burdon Sanderson and William Jenner, both members of the Executive Committee that then recommended the granting of the licence. ${ }^{57}$ Correspondence would be filtered through a formal address at the Royal College of Physicians, and applications managed by a permanent sub-committee and a secretary on 100 Guineas a year. In cases where there might have been doubts, the AAMR resolved not to pass applications back to the Home Office until any necessary revisions had been carried out. They therefore practically eliminated any chance of applications being refused. ${ }^{58}$ For example, one report in support of an application for experiments on dogs was sent by the Home Office to a government appointed inspector, who in turn reported that he was 'unable to see any reason for believing that the experiments proposed ... are calculated, so far as they have any worth, to advance knowledge either practically or scientifically' and that the experiments 'would be attended with considerable suffering, in all probability greater than would be commensurate with any utility to be derived from them'. With such stark condemnation, the Home Office simply asked the AAMR for 'further observations' and the Committee quickly resolved that the application 'be supported'. ${ }^{59}$ A letter quickly followed, 'stating at full length

${ }^{57}$ AAMR Minute of 27 February 1883, Minutes of the Council and Executive, 27, MS.5310, Wellcome Library, London.

58 AAMR Minute of 27 February 1883, Minutes of the Council and Executive, 28, MS.5310, Wellcome Library, London. There was the occasional wrinkle, as with the applications of Yeo and Lockhart Gibson, which had been refused despite significant pressure from the AAMR. They had applied for certificate E, which was specifically for experiments involving cats and dogs without the use of anaesthesia, the most politically and ethically challenging of all categories of research licensing under the Act. AAMR Minutes of 11 January and 15 February 1884, Minutes of the Council and Executive, 32-3, MS.5310, Wellcome Library, London. For how this specific argument with the Home Office played out, see Shmuely, 'Bureaucracy of Empathy', 96-100.

${ }^{59}$ AAMR Minute of 2 February 1886, Minutes of the Council and Executive, 40, MS.5310, Wellcome Library, London. 
the arguments in favour of it and the grounds in which it received the support of the Association'. Within a week, the Home Secretary had granted the licence and certificate B. Lay opinion about suffering, about utility and about the value of experiments for the production of knowledge, could thus be simply swept away by the authority of expertise, delivered in concert through its institutionalization in the AAMR. ${ }^{60}$

There was a massive conflict of interest. The relationship was not publicly acknowledged (indeed, communication from the Home Office was marked 'Pressing \& Confidential'), but it was congenial. At one point in the middle of 1883, the sub-committee charged with dealing with applications and communication with the Home Office reported that 'relations of the Assoc. with the H.O. were at the present time in every way satisfactory and that all communications from the Assoc. received marked courtesy and attention. In one instance, an answer to a pressing request the Home Secretary granted a license and allowed a Certificate B in 2 days' ${ }^{61}$ Medical science had, almost by the power of its own authority with Parliament, safeguarded the growth of experimental medicine irrespective of the restrictive Act by becoming custodian of that Act.

This is all remarkable in its own right, but the AAMR's quickly discovered power should cause a re-assessment of the standard rhetorical lines of argument of the medical-scientific community from 1882 down the First World War. After 1876, it had quickly become orthodox to proclaim in public that the Act had shackled and frustrated medical science, to the great detriment of the pursuit of knowledge and the public good. That had been the leitmotiv of the IMC in 1881, and it coloured the public animadversions of medical scientists for a generation. But behind the scenes, the AAMR had effectively removed any barrier to the continuation and development of experimental research. Complaining about the Act became a device to make sure that no further inroads into experimental freedom could be made by antivivisectionists. If 1876 could be represented as a terrible burden, then it could be used to blunt more radical antivivisectionist cant. The public could be reassured that the antivivisectionists had already won their great victory. In fact, the 1876 Act was a dead letter.

This reappraisal must also throw the other activities of the AAMR and its successor, the Research Defence Society (see Chapter 4) into new light. For while it remains fair to say that the members of the AAMR did consider antivivisectionism a real threat, the arrangement with the Home Office

${ }^{60}$ AAMR Minute of 21 May 1886, Minutes of the Council and Executive, 41, MS.5310, Wellcome Library, London.

${ }^{61}$ AAMR Minute of 25 June 1883, Minutes of the Council and Executive, 30-31, MS.5310, Wellcome Library, London. 
allowed them to promote research in other ways with even more power. For example, in the same sub-committee report that advised the AAMR to seek the ear of the Home Secretary, it was also advised that research be directly funded from AAMR coffers, perhaps even to the extent of sponsoring a laboratory in the field of therapeutics, and with specific intentions to fund research on the causes of tuberculosis. In their second meeting, the sub-committee resolved to request $£ 300$ to cover the personal remuneration of an investigator, over the course of three years, plus expenses, to carry out this work. In addition, they suggested a grant of $£ 100$ to Scottish bacteriologist William Watson Cheyne (1852-1932) to pursue the work of Robert Koch (1843-1910) and Jean Joseph Henri Toussaint (1847-90) on the subject. This included funding for departure from England to follow up directly with Koch. Cheyne's work, once vetted, was then slated for publication in the Practitioner, with additional funds from the Association to copy and distribute it, with interest generated by the posting of an abstract of the research in the prominent medical weeklies. ${ }^{62}$

A further recommendation was made to grant financial support to Charles S. Roy (1854-97) for his research on foot and mouth disease. A close examination of AAMR records shows that the funding of research in this case was directly politically motivated, as a response to Roy's vilification by antivivisectionists towards the end of 1882 . Roy himself had been introduced to a meeting of the Executive Committee, laying upon the table a series of pamphlets and articles, among them a prominent piece by Frances Power Cobbe in the Contemporary Review, that served to highlight the cruelty of Roy's experiments on the innervation of the kidney, which he had described to the IMC in 1881 . There was also an anonymously published piece that called his character into question. The Committee prepared and issued a statement vindicating Roy, for which Roy expressed his gratitude. If this were as far the AAMR had gone in such matters, then it might simply have become a pressure group, seeking to influence public opinion in the exact same manner as the antivivisection societies. But in its capacity also to fund research, the AAMR could add material weight to its defence of researchers' characters, by directly funding their research and by ensuring that there would be no barriers to the securing of licences. Roy received $£ 200$ from Association funds. ${ }^{63} \mathrm{He}$ would be funded again in 1885 , to investigate the Spanish cholera outbreak. ${ }^{64}$

62 AAMR Minute of 27 February 1883, Minutes of the Council and Executive, 27, MS.5310, Wellcome Library, London.

63 AAMR Minute of 11 January 1884, Minutes of the Council and Executive, 32, MS.5310, Wellcome Library, London.

${ }^{64}$ French, Antivivisection, 205-6; AAMR Minute of 28 September 1885, Minutes of the Council and Executive, 38, MS.5310, Wellcome Library, London. 
At Executive Committee meetings it was not uncommon for sitting MPs to be present, by invitation, and for discussions to take place as to the best ways to thwart any new attempts at antivivisectionist legislation. In 1883, for example, R. T. Reid (1846-1923) put forward a Bill for the abolition of vivisection (it was not his first attempt and would not be his last). It never stood a chance of success, given government opposition, but it still afforded an opportunity for the AAMR to exert its influence on public opinion. The Presidents of the Royal Colleges of Physicians and Surgeons could be prevailed upon, for example, to publish letters of opposition in The Times, directed through the discussions of the Committee. ${ }^{65}$ Sir Lyon Playfair's speech in the House of Commons was, with his permission, printed and distributed not only to AAMR members, but to all members of the legislature. ${ }^{66}$ This snapshot of the AAMR's behind-the-scenes activity shows it to have been a slick operation that was defined by conflict of interest, defending character in public, funding research in private, and facilitating research by acting as an arm of government, in a semi-official capacity. All the while, the AAMR devoted considerable time and money to the publication or re-publication and distribution of literature dedicated to the cause of promoting experimental science and medicine using live animals.

While French has characterized an apparent diminution of such sponsored literature by the end of the 1880s as indicative of the AAMR's assumed role of administrator of the 1876 Act, it is more likely that there was simply less need for such literature by the beginning of the 1890 s, and fewer funds to pursue such a course. 1881 had proven to be a great flashpoint in the controversy, but the antivivisectionist cause had been thwarted in court, and then utterly out-manoeuvred by the medical establishment. While the beginning of the twentieth century would see renewed ardour among the antivivisectionists, as well as some longoverdue scrutiny of AAMR ethics, and while individual scientists occasionally ran into administrative difficulties with the working of the Act, it seems reasonable to conclude that the AAMR had effectively ushered in a period of great expansion of experimental work, with little recourse for its opponents in return. Darwin's foot soldiers, helped in no small degree by Darwin's financial legacy, had won a major temporary victory in the defence of experimental medicine.

Nevertheless, the considerable expenditure on research grants, printing and publishing had, despite the AAMR's obvious success among the

${ }^{65}$ AAMR Minute of 2 April 1883, Minutes of the Council and Executive, 29, MS.5310, Wellcome Library, London. William Jenner and T. Spencer Wells, 'The Abolition of Vivisection', The Times, 3 April 1883.

${ }^{66}$ AAMR Minute of 25 June 1883, Minutes of the Council and Executive, 30, MS.5310, Wellcome Library, London. 
medical community, put the Association in financial difficulties by the beginning of 1888 . It boasted only about $£ 100$ in funds and thereafter it offered much less support to active researchers, focusing its efforts on the support of applications for licences and certificates for research from the Home Office. Contra French's interpretation, that the AAMR retreated into silence as a deliberate strategy, it seems more likely that it simply found it impossible to continue its breadth of activities after the initial influx of cash had been dispensed. What the Committee retained was a significant expertise and influence, which it could bring to bear on the Home Office on behalf of scientists active in the field. This came with minimal cost. At the end of 1889 the Association declared itself unable to make any grants, and in 1891, Stephen Paget (1855-1926), the Association Secretary and the son of James, requested that his own salary not exceed $£ 50 .{ }^{67}$ It was becoming a tight ship, but the principal usefulness of the Association still lay in its capacity to influence the Home Secretary, up to the point of changing his mind about proposals for experiments that were initially refused. But basic subscriptions barely covered costs, and there were no more large capital donations, like Darwin's, that had launched the Association with such fanfare. In part, this was a result of the Association's clear success. It had made experimental research possible in Britain, to an extent scarcely imaginable in 1876 , or even in 1881 . It had done so while depending entirely upon the scientific and medical community, and had limited itself to communicating only with that body of professionals. As the scene shifted again, in the early twentieth century, the defence of experiment would have to look, for the first time in a substantial way, beyond the professional community to the lay public. Here, it would find new strategies and new modes of defence, and, importantly, new revenue streams, while reproducing old rhetorical scripts.

${ }^{67}$ AAMR Minute of 8 November 1889 and Minute of 18 June 1891, Minutes of the Council and Executive, 61, 66, MS.5310, Wellcome Library, London. 